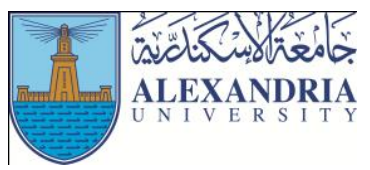

Journal of Applied Sports Science

June 2016, Volume 6, No. 2

www.jass.alexu.edu.eg

\title{
Effect of Blended E-Learning Program on Basic Skill Learning in Basketball Students in the First Class in Faculty of Physical Education at Zagazig University
}

\author{
Hany Ahmed Ahmed Abd El-Aal ${ }^{1}$ \\ ${ }^{1}$ Department of theories and applications of Team Sports, Faculty of Physical Education for male, Zagazig University, Egypt.
}

\begin{abstract}
This research aims to design blended learning teaching program within e-learning website for effective basic skill learning in basketball students in the first class in faculty of physical education at Zagazig University, Experimental approach was using in this study, two groups (experimental and control), 75 young male basketball students from faculty of physical education for male, Zagazig University, Egypt, volunteered to take part in this study, were divided into two groups (experimental group $n=30(E G)$ and control group $n=30(C G)$ ) were selected for this purpose and (15) students for exploratorystudy. Results: (1) Proposed blended e-learning program has a positive effect on students 'basic skills learning in basketball for both groups. (2) rate of improvement for post measures for both groups in skills variables, rate of improvement for experimental group (blended e-learning) were ranged between (24.38\% - 928.40\%), nevertheless the control group (explain \& model) were ranged between (17.88\% - 705.91\%). (3) There are significant statistical differences at $p<.05$ between post measures for both groups experimental group (blended e-learning) and control group (explain \& model) in the skills variables in favor of experimental group.
\end{abstract}

Keywords: blended e-learning - basketball skills.

\section{Introduction}

$\mathrm{T}$ There has been an increase over the world in the number of universities and faculties implementing in Education and blended learning as an integral part of instructional activities. They are trying to make best use of the technology available to promote the e-learning and to motivate sport students to study outside their faculties.

Blended learning or hybrid learning has emerged in higher education for a few years, which combines online and face to face instruction (Young, 2001). As a new delivery mechanism, it can bring effective learning, increase access and flexibility, and reduce cost (Bonk \& Graham, 2012; Lorenzetti, 2005). In addition, students find blended learning very interesting compared to the traditional method of teaching. Web based instruction is already revolutionizing how students work, think, and access information (Russell et al., 2003).

The video in website has the capability to display or replay the sports action or key motion loop and loop. Teacher or coach can explain the action to the students directly through the media repeating the key motion or difficulty slowly (Katz, 1992). Student can learn the course by himself via voice guidance and sample action demoing within the video scene. When students learn the sports skill, to view the action skill repeatedly and supply the diversiform learning method are very important (Mohnsen, 1995; Morrison et al., 2010).

According to (Picciano, 2009), classes where face to face and online activities are integrated in a planned, pedagogically valuable manner and where online activities replace a portion of face to face time, are blended learning classes. Blended learning is a design approach whereby both face to face and online learning are made better by the presence of each other. Another term that has been widely used as an alternative term for blended learning is hybrid learning (So \& Brush, 2008).

On other hand, the blended courses offer a number of advantages over face to face teaching and completely online courses. Research have shown that this combination has the potential of promoting learner-centered, active and constructive learning (Bonk \& Graham, 2012; Lorenzetti, 2005; Russell et al., 2003; Salomon \& Ben-Zvi, 2006). Also, blended learning might improve students' learning experience by developing their capacity for reflection (Cooner, 2010). 
Additionally, blended learning produced a stronger sense of community among students than either traditional or fully online courses. According to (Gómez \& Igado, 2008) blended learning maximizes effectiveness, promotes teacher-learner interaction, access online and physically feedback instantly. Due to the above advantages it had been considered very useful to explore all these possibilities on physical education in tertiary education settings.

Several research studies published in the early have addressed the use of multimedia based computer assisted instruction for the teaching of physical education concepts and skills within sport faculties. In these studies, (McKethan et al., 2000) evaluated the effectiveness of a multimedia application designed to teach cognitive components of motor skills as compared to that of traditional lectures. The students who had attended the lectures were found to score significantly higher on a test of the critical components of the motor skills under study than those who had used the application, although no differences between the two groups were found on a test of cue descriptions of these skills.

Based on blended learning studies, (Melton et al., 2009) evaluated student satisfaction and achievement in a blended learning health course. Participants included 251 students enrolled in sections of the traditional or the blended health course. Although no significant difference was found in pre/posttest scores, students enrolled in the blended sections achieved higher in final course grades. Therefore it can be suggested that both the blended and traditional sections provided the same degree of knowledge acquisition.

Despite the cautious, but yet quite positive feedback, researchers and educators still worry that the blended course option may not be the answer to distance education problems. Students' confusion about the blend of online and traditional delivery methods, increased student workload in blended sections, and weak online components are some of the concerns being raised by (Reasons, 2004). Moreover research in physical education higher education has been limited so far. In this study, a blended learning of instruction was designed and developed to deliver content of learning basic basketball skills.

Due to the specific features of media, courseware which is created based on computer multimedia can satisfy the demands of teaching and learning. Therefore, blended learning application which integrates multimedia elements to apply to sports can supply the sense effect and increase learners' learning motivation and desire. Also, blended learning courseware also plays an assistant role to help teacher and give the diversiform instructional policies to students when students get out of faculty.

Thus, the aim of current study was to design blended learning teaching program within e-learning website for effective basic skill learning in basketball students in the first class in faculty of physical education at Zagazig University.

\section{Procedures}

\section{Subjects:}

Experimental approach was using in this study, two groups (experimental and control), 75 young male basketball students from faculty of physical education for male, Zagazig University, Egypt, volunteered to take part in this study, were divided into two groups (experimental group $n=30$ (EG) and control group $n=30(\mathrm{CG})$ ) were selected for this purpose and (15) students for exploratorystudy. Subjects were randomly assigned $(\mathrm{n}=$ 75: age, $18.40 \pm 0.44$ years old; weight, $72.75 \pm 2.52 \mathrm{~kg}$ and height, $173.67 \pm 2.68 \mathrm{~cm}$ ), respectively (Mean $\pm \mathrm{SD}$ ). Skills variables were randomly assigned (Push-pass, Speed pass, Overarm pass for accuracy, Dribble, Foul shoot, Dribble - shoot test) $11.44 \pm 1.38$ degree, $18.48 \pm$ 1.79 second, $2.43 \pm 1.45$ degree, $52.72 \pm 2.04$ second, 2.36 \pm 1.02 degree and $93.89 \pm 2.13$ second, respectively (Mean $\pm \mathrm{SD})$.

\section{Blended learning program:}

For the purpose of this study course was designed in a blended course format (part online, part face to face) according to Kerres's and De Witt's (2003) (Appendix 1) 3C-model of didactical components in a blended learning arrangement. This model includes three components that need to be taken into account:

- A content component that makes learning material available to the learner.

- A communication component that offers interpersonal exchange between learners or learners and tutors.

- Constructive component that facilitates and guides individual to actively operate on learning tasks with different degrees of complexity (from multiple-choice to projects or problem based learning). In designing the blended course, formal and informal data gathered from students who had previous taken the course, were examined. Then the instructors specified the desired outcomes of the course in terms of goals and objectives. 
At the end, the content, the practice items and the assessment instruments were determined based on the course's basic goals.

The researcher performed the pre-measures on 29/09/2015 up to 30/09/2015 for the experimental group (blended elearning) and the control group (explain \& model). 03/10/2015 Started by applying the specific educational program by blended e-learning for experimental group and control group (explain \& model) for a period of (8) week at the rate of (3) sessions per week for (45) minutes per session, and until 25/11/2015, 28/11/2015, up to $30 / 11 / 2015$ the researcher performed the post measures.

\section{Basketball skills tests:}

Leilich basketball test, Johnson Basketball Ability, Knox basketball test, Lehston basketball test, AAHPER Test for basketball skills, all these battary tests consests of pushpass, speed pass, overarm pass for accuracy, dribble, foul shoot, dribble - shoot test.

\section{Statistical methods:}

The researcher used the SPSS 17.0, statistical program for data processing, statistical significance was set at $\mathrm{P} \leq 0.05$.

\section{Results}

Table (1)

difference significance of pre $\&$ post test of experimental group in skill variables $(\mathrm{N}=30)$

\begin{tabular}{|c|c|c|c|c|c|c|}
\hline & \multirow{2}{*}{ Unit } & \multicolumn{2}{|c|}{ Pre } & \multicolumn{2}{|c|}{ Post } & \multirow{2}{*}{ T-stat } \\
\hline & & Mean & $\mathrm{SD}$ & Mean & $\mathrm{SD}$ & \\
\hline Push-pass & Degree & 11.50 & 1.43 & 46.73 & 2.13 & $73.95 *$ \\
\hline Speed pass & Second & 18.03 & 1.54 & 12.27 & 1.26 & $15.59 *$ \\
\hline Overarm pass for accuracy & Degree & 2.57 & 1.52 & 26.43 & 1.17 & $66.99 *$ \\
\hline Dribble & Second & 52.80 & 1.79 & 39.93 & 1.44 & $30.17 *$ \\
\hline Foul shoot & Degree & 2.43 & 1.01 & 14.10 & 0.88 & $46.91 *$ \\
\hline Dribble - shoot test & Second & 93.67 & 2.26 & 34.07 & 2.05 & $105.19^{*}$ \\
\hline
\end{tabular}

* Significantly different at $\mathrm{p}<.05=2.021$

There are significant differences observed in table (1) between pre-test and post-test of experimental group in all speed pass, overarm pass for accuracy, dribble, foul shoot, dribble - shoot test). variables of skills abilities variables variables (push-pass,

Table (2)

difference significance of pre \& post test of control group in skill variables $(\mathrm{N}=30)$

\begin{tabular}{|c|c|c|c|c|c|c|}
\hline & \multirow{2}{*}{ Unit } & \multicolumn{2}{|c|}{ Pre } & \multicolumn{3}{|c|}{ Post } \\
\cline { 3 - 7 } & & Mean & SD & Mean & SD & \\
\hline Push-pass & Degree & 11.37 & 1.40 & 36.80 & 2.93 & $42.17 *$ \\
\hline Speed pass & Second & 18.23 & 1.96 & 14.97 & 1.54 & $7.04 *$ \\
\hline Overarm pass for accuracy & Degree & 2.37 & 1.59 & 19.10 & 1.47 & $41.61 *$ \\
\hline Dribble & Second & 52.43 & 2.28 & 46.73 & 1.53 & $11.18^{*}$ \\
\hline Foul shoot & Degree & 2.23 & 1.01 & 10.03 & 1.13 & $27.71 *$ \\
\hline Dribble - shoot test & Second & 93.93 & 2.00 & 38.63 & 1.69 & $113.73 *$ \\
\hline
\end{tabular}

* Significantly different at $\mathrm{p}<.05=2.021$

There are significant differences observed in table (2) between pre-test and post-test of control group in all variables of skills abilities variables variables (push-pass, speed pass, overarm pass for accuracy, dribble, foul shoot, dribble - shoot test). 
Table (3)

difference significance of both post tests of experimental \& control groups in skill variables $(\mathrm{N}=30)$

\begin{tabular}{|c|c|c|c|c|c|c|}
\hline \multirow{2}{*}{ Variables } & \multirow{2}{*}{ Unit } & \multicolumn{2}{|c|}{ experimental } & \multicolumn{3}{|c|}{ control } \\
\cline { 3 - 6 } & & Mean & SD & Mean & SD & \\
\hline Push-pass & Degree & 46.73 & 2.13 & 36.80 & 2.93 & $14.76^{*}$ \\
\hline Speed pass & Second & 12.27 & 1.26 & 14.97 & 1.54 & $7.31^{*}$ \\
\hline Overarm pass for accuracy & Degree & 26.43 & 1.17 & 19.10 & 1.47 & $21.01^{*}$ \\
\hline Dribble & Second & 39.93 & 1.44 & 46.73 & 1.53 & $17.43^{*}$ \\
\hline Foul shoot & Degree & 14.10 & 0.88 & 10.03 & 1.13 & $15.30^{*}$ \\
\hline Dribble - shoot test & Second & 34.07 & 2.05 & 38.63 & 1.69 & $9.24^{*}$ \\
\hline
\end{tabular}

* Significantly different at $\mathrm{p}<.05=2.021$

There are significant differences observed in table (3) between post-tests of both experimental and control group pass, speed pass, overarm pass for accuracy, dribble, foul shoot, dribble - shoot test). in all variables of skills abilities variables variables (push-

Table (4)

percentage of improvement for post measures for both groups in skills variables

\begin{tabular}{|c|c|c|c|c|c|c|c|}
\hline \multirow{2}{*}{ Variables } & \multirow{2}{*}{ Unit } & \multicolumn{2}{|c|}{ experimental } & \multicolumn{4}{|c|}{ control } \\
\cline { 3 - 9 } & & Pre & Post & $\%$ & Pre & Post & $\%$ \\
\hline Push-pass & Degree & 11.50 & 46.73 & 306.35 & 11.37 & 36.80 & 223.66 \\
\hline Speed pass & Second & 18.03 & 12.27 & 31.95 & 18.23 & 14.97 & 17.88 \\
\hline Overarm pass for accuracy & Degree & 2.57 & 26.43 & 928.40 & 2.37 & 19.10 & 705.91 \\
\hline Dribble & Second & 52.80 & 39.93 & 24.38 & 52.43 & 46.73 & 10.87 \\
\hline Foul shoot & Degree & 2.43 & 14.10 & 480.25 & 2.23 & 10.03 & 349.78 \\
\hline Dribble - shoot test & Second & 93.67 & 34.07 & 63.63 & 93.93 & 38.63 & 58.87 \\
\hline
\end{tabular}

Table (4) shows rate of improvement for post measures for both groups in skills variables, rate of improvement for experimental group (blended e-learning) were ranged between $(24.38 \%$ - 928.40\%), nevertheless the control group (explain \& model) were ranged between $(17.88 \%$ $705.91 \%$ ). With expansion for experimental group which use blended e-learning.

\section{Discussion}

Improvement in post-test is a result to the blended elearning program, a possible explanation for these findings may be that the significantly improved results for the knowledge test occurred because students took advantage of the extra learning opportunities provided through the BLI. According to Sparrow et al. (2000), the online components promoted student-centered learning in a way that provides significant autonomy for students in terms of time place and occurrence of their study (Sparrow et al., 2000). Also the feedback supplied through quizzes, students' paper and forums might have helped students to learn from their mistakes, a fact that influenced the improved results in the knowledge test for those students exposed to the blended approach.
As deduced from the results, within both groups, significant increases in students' basketball skills were found. However, the blended e-learning program course combined with traditional instruction was significantly more effective than traditional instruction alone in helping students acquire basketball-related skills. These findings seem to contrast with those of two other studies (Bennett 2002; Leser et al. 2011), in which blended e-learning program environments were used for the learning of PE concepts and skills at HE level.

These results are on line with studies of (1), (5), (11), (15) that applying blended e-learning in educational and training programs leading to develop basic motor skills in many sport activities.

The results of this study appear to be consistent with the results of a number of studies that have previously been reviewed (El-Deghaidy \& Nouby, 2008; McFarlin, 2008; Pereira et al, 2007; Vernadakis et al, 2011). These studies have highlighted the effectiveness of blended learning in improving students' achievement. Therefore the instructor's presence coupled with the flexibility of elearning method in terms of time and place seemed to provide a chance for students to thoroughly review the educational material besides performing other activities. 
The main finding of the current study suggests that the implementation of blended learning instruction had a practical significance with regard to improving students' achievement in the subject of basketball skills.

Increasing in improvement for experimental group is a result of applying blended e-learning.

There is limitation that need to be acknowledged and addressed regarding the present study. The limitation concerns the sample of this study. Students included in this study were only from the faculty of physical education at Zagazig University, Egypt. A larger and more diverse sample would provide a wider approach for cognitive learning.

\section{Conclusions}

(1) Proposed blended e-learning program has a positive effect on students' basic skills learning in basketball for both groups. (2) rate of improvement for post measures for both groups in skills variables, rate of improvement for experimental group (blended e-learning) were ranged between $(24.38 \%$ - 928.40\%), nevertheless the control group (explain \& model) were ranged between $(17.88 \%$ $705.91 \%$ ). (3) There are significant statistical differences at $\mathrm{p}<.05$ between post measures for both groups experimental group (blended e-learning) and control group (explain \& model) in the skills variables in favor of experimental group.

\section{References}

1- Bennett, G. (2002). Web-based instruction in sport management. Sport Management Review, 5, 45-68.

2- Bonk, Curtis J, \& Graham, Charles R. (2012). The handbook of blended learning: Global perspectives, local designs: John Wiley \& Sons.

3- Cooner, Tarsem Singh. (2010). Creating opportunities for students in large cohorts to reflect in and on practice: Lessons learnt from a formative evaluation of students' experiences of a technology-enhanced blended learning design. British Journal of Educational Technology, 41(2), 271-286.

4- El-Deghaidy, H. \& Nouby, A. (2008). Effectiveness of a blended e-learning cooperative approach in an Egyptian teacher education programme. Computers \& Education, 51(3), 988-1006.

5- Gómez, J, \& Igado, M. (2008). Blended Learning: The Key to Success in a Training Company. International Journal of Instructional Technology and Distance Learning, 5(8), 33-42.
6- Katz, L. (1992). The role of interactive video, multimedia and technology in Physical Education: Towards the years 2000. Paper presented at the Processing of the International conference on computer Application in Sport and Physical Education.

7- Kerres, M. \& De Witt, C. (2003). A didactical framework for the design of blended learning arrangements. Journal of Educational Media, 28(2/3), $101-113$.

8- Leser, R., Baca, A., \& Uhlig, J. (2011). Effectiveness of multimedia-supported education in practical sports courses. Journal of Sports Science and Medicine, 10(1), 184-192.

9- Lorenzetti, J. (2005). Lessons learned about student issues in online learning. Distance Education Report, 9(6), $1-4$.

10- McFarlin, B. K. (2008). Hybrid lecture-online format increases student grades in an undergraduate exercise physiology course at a large urban university. Advances in Physiology Education, 32, 86-91.

11- McKethan, Robert, Everhart, Brett, \& Stubblefield, Erik. (2000). The Effects of a Multimedia Computer Program on Preservice Elementary. The Physical Educator, 57(2).

12- Melton, Bridget Frugoli, Bland, Helen W, \& ChopakFoss, Joanne. (2009). Achievement and satisfaction in blended learning versus traditional general health course designs. International Journal for the Scholarship of Teaching and Learning, 3(1), 26.

13- Mohnsen, Bonnie S. (1995). Using technology in physical education: Human Kinetics Publishers.

14- Morrison, Gary R, Ross, Steven M, Kemp, Jerrold E, \& Kalman, Howard. (2010). Designing effective instruction: John Wiley \& Sons.

15- Pereira, J., Pleguezuelos, E., Meri, A., Molina-Ros, A., Molina-Tomas, M. \& Masdeu, C. (2007). Effectiveness of using blended learning strategies for teaching and learning in human anatomy. Medical Education, 41 (2), 189-195.

16- Picciano, Anthony. (2009). Blending with purpose: The multimodal model. Journal of the Research Center for Educational Technology, 5(1), 4-14.

17- Reasons, Saxon G. (2004). Hybrid courses-hidden dangers. Distance Education Report, 8(7), 3-6.

18- Russell, Michael, Bebell, Damian, O'Dwyer, Laura, \& O'Connor, Kathleen. (2003). Examining teacher technology use implications for preservice and inservice 
teacher preparation. Journal of Teacher Education, 54(4), 297-310.

19- Salomon, Gavriel, \& Ben-Zvi, Dani. (2006). The difficult marriage between education and technology: Is the marriage doomed. Instructional psychology: Past, present and future trends: Essays in honor of Erik De Corte, 209-222.

20- So, Hyo-Jeong, \& Brush, Thomas A. (2008). Student perceptions of collaborative learning, social presence and satisfaction in a blended learning environment: Relationships and critical factors. Computers \& Education, 51(1), 318-336.
21- Sparrow, L., Sparrow, H., \& Swan, P. (2000, February). Student centred learning: Is it possible. In Flexible futures in tertiary teaching. Proceedings of the 9th Annual Teaching Learning Forum (pp. 2-4).

22- Vernadakis, N., Antoniou, P., Giannousi, M., Zetou, E. \& Kioumourtzoglou, E. (2011). Comparing hybrid learning with traditional approaches on learning the Microsoft Office Power Point 2003 program in tertiary education. Computers \& Education, 56(1), 188-199.

23- Young, J. R. (2002). Hybrid teaching seeks to end the divide between traditional and online instruction. Chronicle of Higher Education, 48(28), A33. 